University of Nebraska - Lincoln

DigitalCommons@University of Nebraska - Lincoln

1991

\title{
Modeling Canopy Photosynthesis: Scaling up from a Leaf to Canopy in a Temperate Grassland Ecosystem
}

S. B. Verma

University of Nebraska - Lincoln

Follow this and additional works at: https://digitalcommons.unl.edu/natrespapers

Part of the Natural Resources and Conservation Commons, Natural Resources Management and Policy Commons, and the Other Environmental Sciences Commons

Verma, S. B., "Modeling Canopy Photosynthesis: Scaling up from a Leaf to Canopy in a Temperate Grassland Ecosystem" (1991). Papers in Natural Resources. 1206.

https://digitalcommons.unl.edu/natrespapers/1206

This Article is brought to you for free and open access by the Natural Resources, School of at DigitalCommons@University of Nebraska - Lincoln. It has been accepted for inclusion in Papers in Natural Resources by an authorized administrator of DigitalCommons@University of Nebraska - Lincoln. 


\title{
Modeling canopy photosynthesis: scaling up from a leaf to canopy in a temperate grassland ecosystem*
}

\author{
Joon Kim and Shashi B. Verma \\ Department of Agricultural .. Meteorology, University of Nebraska-Lincoln, Lincoln. NE 68583.0728, \\ USA
}

(Received 29 October 1990; revision accepted 12 February 1991)

\begin{abstract}
Kim, J. and Verma, S.B., 1991. Modeling canopy photosynthesis: scaling up from a leaf to canopy in a temperate grassland ecosystem. Agric. For. Meteorol., 57: 187-208.

A biochemical model of leaf photosynthesis, in conjunction with a stomatal conductance model, was applied to $\mathrm{C}_{4}$ tallgrass species (Andropogon gerardii. Sorghastrum nutans. Panicum virgatum) in northeastern Kansas, USA. The modeled photosynthetic rates of individual leaves were scaled up to the canopy level using a simple canopy radiative transfer model. Comparisons with field measurements, using the micrometeorological eddy correlation technique, showed that the model simulated the magnitudes and the diumal variations of canopy photosynthesis adequately under well-watered conditions. Although the model overestimated measured canopy photosynthesis by $4-7 \mu \mathrm{mol} \mathrm{m}^{-2}$ $\mathrm{s}^{-1}$ under moisture stress conditions (where $1 \mu \mathrm{mol} \mathrm{m}^{-2} \mathrm{~s}^{-1} \approx 0.044 \mathrm{mg} \mathrm{m}^{-2} \mathrm{~s}^{-1}$ ), it did seem to simulate the diurnal patterns (e.g. morning peak) realistically. Using similar scaling-up procedures. values of canopy stomatal conductance were also computed from the model. The modeled canopy stomatal conductance agreed with measured values reasonably well (within $0.2 \mathrm{~mol} \mathrm{~m}^{-2} \mathrm{~s}^{-1}$, where $1 \mathrm{~mol} \mathrm{~m}^{-2} \mathrm{~s}^{-1} \approx 0.0249 \mathrm{~m} \mathrm{~s}^{-1}$ when $P=100 \mathrm{kPa}$ and $T=300^{\circ} \mathrm{K}$, under well-watered conditions and within $0.05 \mathrm{~mol} \mathrm{~m}^{-2} \mathrm{~s}^{-1}$ under moisture stress conditions ).
\end{abstract}

\section{INTRODUCTION .}

While much has been learned about the photosynthetic responses of individual leaves to changing environmental conditions, less is known about these processes at the canopy level (e.g. Hesketh, 1980). The information on canopy photosynthesis in various terrestrial ecosystems is particularly important in studies of ecophysiological modeling, carbon balance and global climate change (Fung et al., 1983; Sellers et al., 1986; Box, 1988; Gifford, 1989).

Carbon dioxide exchange between vegetation and the atmosphere can be

-Published as Paper No. 9287, Journal Series, Agricultural Research Division, University of Nebraska-Lincoln.

0168-1923/91/\$03.50 @ 1991 Elsevier Science Publishers B.V. All rights reserved. 
directly measured by micrometeorological methods (flux-gradient or eddy correlation technique, see e.g. Kaimal, 1975; Kanemasu et al., 1979; Baldocchi et al., 1988; Verma, 1990). These techniques cause minimal disturbance and provide area-integrated fluxes. The results obtained from these methods include $\mathrm{CO}_{2}$ emanated from the soil, which needs to be separated to obtain canopy photosynthesis. Canopy photosynthesis may also be estimated by integrating individual leaf net photosynthesis over the whole canopy. In this approach, detailed models of leaf photosynthesis and the canopy microclimate are needed.

Based on the assumption that photosynthesis may be explained on the basis of the kinetics of ribulose-1,5,-bisphosphate carboxylase-oxygenase (RuBisCO), Farquhar et al. (1980) proposed a biochemical model of photosynthesis in leaves of $\mathrm{C}_{3}$ species. The model predicts $\mathrm{CO}_{2}$ assimilation independent of stomatal limitations and can be linked to a stomatal conductance model to examine the distribution of photosynthetic control between the stomata and leaf biochemistry (Ball et al., 1987; Norman and Arkebauer, 1991). Practical application of this biochemical model to predicting canopy photosynthesis requires information on the maximum velocity of carboxylation, the light-saturated rate of electron transport, dark respiration rate, intercellular partial pressure of $\mathrm{CO}_{2}$, leaf temperature and photosynthetically active radiation absorbed by the leaf (Farquhar and Von Caemmerer, 1982). With the development of more compact, field-portable gas-exchange systems, most of the variables described above can be estimated from laboratory and field measurements. Harley et al. (1985) applied the Farquhar et al. (1980) model to soybean and estimated the parameters from leaf gas exchange measurements. Tenhunen and Harley (1988) applied the Farquhar et al. model to a Portuguese macchia (Quercus coccifera). They found that model simulations were least successful during periods of extreme stress. Price and Black (1989) adapted this model to predict canopy photosynthesis and water use efficiency over a Douglas-fir forest. They found poor agreement between predicted and measured data. and attributed this difference mainly to deficiencies in the information required to characterize diurnal responses of canopy photosynthesis. Using the laboratory determinations of RuBisCO kinetics, Grant (1989) and Grant et al. (1989) adapted the Farquhar et al. model to simulate leaf photosynthesis of maize $\left(C_{4}\right)$ and soybeans $\left(C_{3}\right)$. Norman and Polley (1989) and Polley et al. (1991) applied the Farquhar et al. model to $\mathrm{C}_{4}$ grass species in a tallgrass prairie, and developed information on the relevant parameters of RuBisCO kinetics from their field measurements of leaf photosynthesis and intercellular $\mathrm{CO}_{2}$ concentration.

Here, we employ the Farquhar et al. model to estimate canopy photosynthesis in a tallgrass prairie, using the information on pertinent parameters developed by Polley et al. (1991). The leaf model is combined with a stomatal conductance model and. therefore, changes in photosynthetic response in 
our model are due to changes in both stomatal conductance and mesophyll capacity for photosynthesis. The objective of this study is to evaluate whether modeled leaf photosynthesis and stomatal conductance can be scaled up to the canopy level to provide canopy photosynthesis and canopy stomatal conductance in a prairie characterized by mixed vegetation. The values from the model are compared with those measured with the micrometeorological eddy correlation technique.

\section{MATERIALS AND METHODS}

\section{Field measurements}

The field data were obtained at a tallgrass prairie site $\left(39^{\circ} 03^{\prime} \mathrm{N}, 96^{\circ} 32^{\prime} \mathrm{W}\right.$, $445 \mathrm{~m}$ above m.s.l.) in northeastern Kansas during the first ISLSCP (International Satellite Land Surface Climatology Project) Field Experiment (FIFE) (for details, see Sellers et al., 1988) in 1987. The soil is predominantly Dwight silty clay loam (Typic Natrustolls). The prairie vegetation is dominated by three $\mathrm{C}_{4}$ grass species: Andropogon gerardii, Sorghastrum nutans and Panicum virgatum (see Table 1 ). The vegetation on the prairie was burned in spring of 1987 . The experimental area had been lightly grazed for several years, but was not grazed in 1986 and 1987.

Fluxes of atmospheric $\mathrm{CO}_{2}$, water vapor, sensible heat and momentum were measured with eddy correlation sensors mounted $2.25 \mathrm{~m}$ above the ground. Photosynthetically active radiation was measured with a quantum sensor mounted $2.0 \mathrm{~m}$ above the ground. Profiles of mean air temperature and humidity were measured with aspirated ceramic wick psychrometers. Mean wind speed was measured with three-cup anemometers. Details on the microme-

TABLE I

Species composition (\%) at the experimental site during the flowering stage in 1987 (after Kim and Verma. 1990b)

\begin{tabular}{lc}
\hline Species & $\%$ \\
\hline Andropogon gerardii (Big bluestem) $\left(C_{4}\right)$ & 27.1 \\
Sorghastrum nutans (Indiangrass) $\left(C_{4}\right)$ & 22.2 \\
Panicum virgatum (Switchgrass) $\left(C_{4}\right)$ & 16.6 \\
Sporobolus asper (Tall dropseed) $\left(C_{4}\right)$ & 7.0 \\
Schizachyrium scoparium (Little bluestem) $\left(C_{4}\right)$ & 4.7 \\
Bouteloua gracilis (Blue grama) $\left(C_{4}\right)$ & 4.3 \\
Dichanthelium oligosanthes (Scribner panicum) $\left(C_{3}\right)$ & 4.0 \\
fgropyron smithii (Western wheatgrass) $\left(C_{3}\right)$ & 1.2 \\
Other grasses & 2.4 \\
Sedges & 6.3 \\
Forbs and woody plants & 4.2 \\
\hline
\end{tabular}


teorological instrumentation and procedure can be found in Kim and Verma (1990a,b).

Leaf water potential was measured hourly (with a pressure chamber) on four fully expanded, sunlit leaf blades of tillers of $A$. gerardii, S. nutans and $P$. virgatum during June-August. The leaf blades were bagged at sampling to prevent tissue water loss. The green leaf area index $(L)$ of each grass species was measured with a portable area meter. Canopy height and leaf width of each grass species were also measured. The surface soil water content $(0-0.1 \mathrm{~m})$ was monitored gravimetrically almost every day and subsurface soil water content $(0.1-1.4 \mathrm{~m})$ was measured with a neutron probe on a weekly basis.

\section{Theoretical consideration}

\section{Modeling leaf photosynthesis:}

The net photosynthetic rate $(A)$ for an individual leaf was calculated based on the work of Farquhar et al. (1980)

$A=\left(1-\Gamma_{*} / C_{\mathrm{i}}\right) \min \left\{W_{\mathrm{c}}, J^{\prime}\right\}-R_{\mathrm{d}}$

where $\Gamma_{*}$ represents the $\mathrm{CO}_{2}$ compensation point in the absence of dark respiration $\left(R_{\mathrm{d}}\right), C_{\mathrm{i}}$ is the intercellular partial pressure of $\mathrm{CO}_{2}, W_{\mathrm{c}}$ is the RuBP (ribulose bisphosphate) saturated rate of carboxylation and $J^{\prime}$ is the maximum rate of carboxylation allowed by electron transport. The values of various parameters used in, this study are given in the Appendix. The term, $\min \{\}$, denotes 'minimum of'. $W_{\mathrm{c}}$ is assumed to obey competitive Michaelis-Menten kinetics and is given by (Farquhar et al., 1980; Von Caemmerer and Farquhar, 1984)

$$
W_{\mathrm{c}}=V_{\mathrm{c}(\max )} C_{\mathrm{i}} /\left[C_{\mathrm{i}}+K_{\mathrm{c}}\left(1+O / K_{\mathrm{o}}\right)\right]
$$

where $V_{\mathrm{c}(\max )}$ is the maximum carboxylation velocity, $O$ is the intercellular partial pressure of oxygen, and $K_{\mathrm{c}}$ and $K_{\mathrm{o}}$ are the Michaelis-Menten constants for $\mathrm{CO}_{2}$ and oxygen, respectively.

The temperature dependence of the kinetic properties of RuBP carboxylase-oxygenase (i.e. $V_{\mathrm{c}(\max )}, K_{\mathrm{c}}$ and $\left.K_{\mathrm{o}}\right)$ were described by the Arrhenius functions, normalized with respect to $25^{\circ} \mathrm{C}$ (Badger and Collatz, 1977; Farquhar et al., 1980)

Parameter $=$ Parameter $\left(@ 25^{\circ} \mathrm{C}\right) \exp \left[E\left(T_{1}-25\right) /\left(298 R T_{k}\right)\right]$

where $E$ is the relevant activation energy, $R$ is the gas constant. and $T_{1}$ and $T_{\mathrm{k}}$ are leaf temperatures in ${ }^{\circ} \mathrm{C}$ and $\mathrm{K}$, respectively.

The electron transport limit on the rate of carboxylation. $J^{\prime}$, is given by (Farquhar and Von Caemmerer, 1982) 
$J^{\prime}=J C_{\mathrm{i}} /\left(4.5 C_{\mathrm{i}}+10.5 \Gamma_{\star}\right)$

where $J$ is the potential rate of electron transport, which depends on the absorbed photosynthetically active radiation $(I)$.

The light dependency of $J$ is approximated by a non-rectangular hyperbola following Polley et al. (1991)

$\theta J^{2}-J\left(J_{\max }+I / 3.3\right)+J_{\max } I / 3.3=0$

where $\Theta$ defines the convexity of the curve and $J_{\max }$ is the light-saturated rate of electron transport. In this study, the photosynthetically active radiation (PAR) absorbed by the leaf was calculated as the product of incident PAR and leaf absorptivity $(\alpha)$. Values of $\alpha$ were calculated from the leaf reflectance and transmittance measurements made in a concurrent study by B.L. Blad and E.A. Walter-Shea (unpublished data, 1990). The analysis by Walter-Shea et al. (1990) indicated that $\alpha$ was not affected by moisture stress for leaf water potentials ranging from -0.5 to $-2.5 \mathrm{MPa}$.

Using the temperature function from Schoolfield et al. (1981), Polley et al. (1991) described $J_{\max }$ as

$J_{\max }=\frac{a_{1} \exp \left\{a_{2}\left[(1 / 298)-\left(1 / T_{\mathrm{k}}\right)\right] / R\right\}}{\left.1+\exp \left\{a_{3}\left[\left(1 / a_{4}\right)-\left(1 / T_{\mathrm{k}}\right)\right] / R\right\}+\exp \left\{a_{5}\left[\left(1 / a_{6}\right)-1 / T_{\mathrm{k}}\right)\right] / R\right\}}$

where $T_{\mathrm{k}}$ is leaf temperature (K), $a_{1}$ is a constant determined from the data of Polley et al. (1991), and $a_{2}-a_{6}$ are the parameters associated with the ratecontrolling enzyme reaction (H.W. Polley, personal communication, 1990).

The dark respiration rate, $R_{\mathrm{d}}$, depends mainly on temperature (Norman and Polley, 1989). The dependence of $R_{\mathrm{d}}$ on the light conditions of the leaf has also been reported (e.g. Anderson and Osmond, 1987). The temperature dependency of $R_{\mathrm{d}}$ is described as (e.g. Norman and Polley, 1989; Polley et
al., 1991)

$R_{\mathrm{d}}=R_{\mathrm{d}}\left(@ 25^{\circ} \mathrm{C}\right) \exp \left[E\left(T_{1}-25\right) /\left(298 R T_{\mathrm{k}}\right)\right]$

Following Polley et al. (1991), the dark respiration rate was suppressed by $50 \%$ when $I>20 \mu \mathrm{mol}$ quanta $\mathrm{m}^{-2} \mathrm{~s}^{-1}$ to accomodate the light dependency of mitochondrial respiration (Sharp et al., 1984; Brooks and Farquhar, 1985).

Recent studies have indicated that the RuBP-carboxylase activity and the regeneration of RuBP are reduced by water stress (e.g. Sharkey and Badger, 1982; Von Caemmerer and Farquhar, 1984; Sharkey and Seemann, 1989). Based on the measurements of Polley et al. (1991), we approximated the dependency of $V_{c(\max )}$ and $J_{\max }$ on leaf water potential $\left(\Psi_{L}\right)$ for the three grass species using the following equations (e.g. Richards, 1969)

$V_{\mathrm{c}(\max )}=V_{\mathrm{c}(\max )}\left(@ \Psi_{L}=0\right) /\left\{1+1000 \exp \left[-3.5\left(\Psi_{L}+3\right)\right]\right\}^{1 /(1-m)}$ 
and

$$
J_{\max }=J_{\max }\left(@ \Psi_{\mathrm{L}}=0\right) /\left\{1+2500 \exp \left[-4.0\left(\Psi_{\mathrm{L}}+3\right)\right]\right\}^{1 /(1-n)}
$$

The terms $m$ and $n$ determine the values of $V_{c(\max )}$ and $J_{\max }$ at which the inflection point occurs.

Previous studies suggest that the stomatal conductance $\left(g_{\mathrm{s}}\right)$ is correlated with the rate of $\mathrm{CO}_{2}$ assimilation $(A)$ (Wong et al., 1979; Jarvis and Morison, 1981; Farquhar and Sharkey, 1982). To realistically simulate the leaf photosynthetic responses to changing environmental conditions, a leaf photosynthesis model should be linked with a stomatal conductance model (e.g Norman, 1986; Tenhunen and Harley, 1988; Norman and Polley, 1989). The relationship between $A$ and $g_{s}$ can be described as follows (e.g. Norman and Polley, 1989)

$$
A=\left(C_{\mathrm{a}}-C_{\mathrm{i}}\right) /\left(1.6 r_{\mathrm{s}}+1.37 r_{\mathrm{l}}\right)
$$

This equation can be rearranged

$$
1 / g_{\mathrm{s}}=r_{\mathrm{s}}=\left(C_{\mathrm{a}}-C_{\mathrm{i}}\right) /(1.6 A)-1.37 r_{\mathrm{l}} / 1.6
$$

where $C_{\mathrm{a}}$ is the partial pressure of ambient $\mathrm{CO}_{2}, r_{\mathrm{s}}\left(=1 / g_{\mathrm{s}}\right)$ is the stomatal resistance for water vapor, 1.6 is the ratio of diffusivities of $\mathrm{CO}_{2}$ and water vapor in air, $r_{1}$ is the leaf boundary-layer resistance for both sides of a leaf, and 1.37 is the ratio of the rates at which $\mathrm{CO}_{2}$ and water vapor are transferred in the leaf boundary layer (the rates are assumed to be proportional to the two-thirds power of their diffusivities, see e.g. Ball, 1987). The leaf boundary-layer resistance was calculated using an empirical equation (J.M. Norman, personal communication, 1990)

$r_{1}=180(l / u)^{1 / 2}$

where $r_{1}$ is in $\mathrm{s} \mathrm{m}^{-1}, l$ is the leaf width $(\mathrm{m})$ and $u$ is the wind speed $\left(\mathrm{m} \mathrm{s}^{-1}\right)$. (We used the wind speed at the canopy top. This value was calculated from the wind speed measured at $1.25 \mathrm{~m}$ above the ground using the logarithmic wind profile equation under neutral atmospheric stability. The canopy height ranged from 0.3 to $0.8 \mathrm{~m}$.)

To initiate the computation we assumed $C_{\mathrm{i}} \approx 0.37 C_{\mathrm{a}}$ (for $\mathrm{C}_{4}$ leaves under normal conditions; J.M. Norman, personal communication, 1990), and calculated $A$ using eqn. (1) at given values of PAR, $T$ and $\Psi_{\mathrm{L}}$. (Air temperature near the canopy top was used instead of leaf temperature $(T)$. Half-hourly values of $\Psi_{L}$ were obtained by interpolating hourly measurements of $\Psi_{L}$. Here we assumed that $T, \Psi_{\mathrm{L}}, D$ and $u$ are constant within the canopy.) With these values of $A$ and $C_{\mathrm{i}}$, we calculated $g_{\mathrm{s}}$ using eqn. (10). The response of stomata to vapor pressure deficit, $D$, was incorporated (Kim and Verma, 1991) as

$$
g_{\mathrm{s}}=g_{\mathrm{s}}(@ D=0) /\left(1+b_{\mathrm{D}} D\right)
$$


where $b_{\mathrm{D}}$ is a constant.

From eqns. ( 1 ) and (10) we obtain

$a C_{\mathrm{i}}^{2}+b C_{\mathrm{i}}+c=0$

where $a=\left(1.6 / g_{\mathrm{s}}+1.37 r_{\mathrm{a}}\right)^{-1}$

$b=\min \left\{W_{\mathrm{c}}, J^{\prime}\right\}-R_{\mathrm{d}}-C_{\mathrm{a}}\left(1.6 / g_{\mathrm{s}}+1.37 r_{\mathrm{a}}\right)^{-1}$

$c=-\Gamma_{*} \min \left\{W_{\mathrm{c}}, J^{\prime}\right\}$

Using the computed values of $g_{\mathrm{s}}, r_{\mathrm{a}}, W_{\mathrm{c}}, J^{\prime}$ and $R_{\mathrm{d}}$, eqn. (13) was solved for $C_{\mathrm{i}}$. Finally, using this value of $C_{\mathrm{i}}$, the value of net leaf photosynthetic rate $(A)$ was calculated from eqn. (1).

Scaling up from a leaf to canopy

Equation (1) was scaled up from a leaf to the canopy level by serially integrating the photosynthetic rates of sunlit and shaded leaves weighted by the fractions of sunlit and shaded leaf areas

$A_{\mathrm{c}}=L_{\text {sun }} \times A_{\text {sun }}+L_{\text {shade }} \times A_{\text {shade }}$

where $A_{\mathrm{c}}$ is the canopy photosynthesis, $L_{\text {sun }}$ and $L_{\text {shade }}$ are the sunlit and shaded leaf area indices, respectively, and $A_{\text {sun }}$ and $A_{\text {shade }}$ are the photosynthetic rates of sunlit and shaded leaves, respectively. For the prairie site studied here, the foliage distribution was relatively uniform and continuous in space. Based on the assumptions that the leaf inclination distribution was spherical and that the foliage in the canopy was randomly distributed, $L_{\text {sun }}$ and $L_{\text {shade }}$ were computed as (e.g. Campbell, 1977; Kim and Verma, 1991)

$L_{\text {sun }}=[1-\exp (-0.5 L / \cos \theta)] 2 \cos \theta$

$L_{\text {shade }}=L-L_{\text {sun }}$

where $\theta$ is the zenith angle of the sun. The flux densities of absorbed PAR by the sunlit leaves $\left(I_{\text {sun }}\right)$ and by the shaded leaves $\left(I_{\text {shade }}\right)$ were estimated as (e.g. Norman, 1982; Kim and Verma, 1991)

$$
\begin{aligned}
I_{\text {sun }}= & \alpha R_{\text {sun }} \\
= & \alpha\left(0.5 R_{\text {dir }} / \cos \theta+R_{\text {shade }}\right), \\
I_{\text {shade }} & =\alpha R_{\text {shade }} \\
& =\alpha\left[R_{\text {diff }} \exp \left(-0.5 L^{0.7}\right)+0.07 R_{\text {dir }}(1.1-0.1 L) \exp (-\cos \theta)\right]
\end{aligned}
$$

where $\alpha$ is the leaf absorptivity, $R_{\text {sun }}$ and $R_{\text {shade }}$ are the flux densities of PAR on sunlit and shaded leaves, respectively. $R_{\mathrm{dir}}$ and $R_{\mathrm{diff}}$ are the flux densities of direct and diffuse PAR above the canopy. To obtain $R_{\mathrm{dir}}$ and $R_{\mathrm{din}}$, the measured incoming PAR was separated into direct and diffuse components of PAR using the procedure of Weiss and Norman (1985).

Since the prairie vegetation mainly consisted of $A$. gerardii, $S$. nutans and 
$P$. virgatum, the canopy net photosynthesis was weighted by the fractions of leaf areas of these three grass species (the sum of $L$ of $A$. gerardii, $S$. nutans and $P$. virgatum accounted for $70-85 \%$ of the total $L$; the $L$ of each grass species was, therefore adjusted such that the sum of $L$ of three grass species was equal to the total $L$ ), and, therefore, $A_{\mathrm{c}}$ of the prairie vegetation was expressed as

$$
\begin{aligned}
A_{\mathrm{c}} & =\left(L_{\text {sun }} \times A_{\text {sun }}+L_{\text {shade }} \times A_{\text {shade }}\right)_{\mathrm{AG}} \\
& +\left(L_{\text {sun }} \times A_{\text {sun }}+L_{\text {shade }} \times A_{\text {shade }}\right)_{\mathrm{SN}} \\
& +\left(L_{\text {sun }} \times A_{\text {sun }}+L_{\text {shade }} \times A_{\text {shade }}\right)_{\mathrm{PV}}
\end{aligned}
$$

where the subscripts AG, SN and PV represent $A$. gerardii, $S$. nutans and $P$. virgatum, respectively. Similarly, the canopy stomatal conductance $\left(g_{\mathrm{s}}\right)$ was calculated by appropriately weighting $g_{s}$ (obtained from eqn. (10)) by the fractions of sunlit and shaded leaf areas

$$
\begin{aligned}
\boldsymbol{g}_{\mathrm{s}} & =\left[L_{\text {sun }} \times g_{\mathrm{s}(\text { sun })}+L_{\text {shade }} \times g_{\mathrm{s}(\text { shade })}\right]_{\mathrm{AG}} \\
& +\left[L_{\mathrm{sun}} \times g_{\mathrm{s}(\text { sun })}+L_{\text {shade }} \times g_{\mathrm{s}(\text { shade })}\right]_{\mathrm{sN}} \\
& +\left[L_{\mathrm{sun}} \times g_{\mathrm{s}(\text { sun })}+L_{\text {shade }} \times g_{\mathrm{s}(\text { shade })}\right]_{\mathrm{PV}}
\end{aligned}
$$

where $g_{\mathrm{s}(\text { sun })}$ and $g_{\mathrm{s}(\text { shade) }}$ are $g_{\mathrm{s}}$ of sunlit and shaded leaves, respectively.

\section{Estimation of soil plus root respiration}

As mentioned above, the eddy correlation measurement of atmospheric $\mathrm{CO}_{2}$ flux (measured above the canopy) provides the sum of canopy and soil (plus root ) $\mathrm{CO}_{2}$ fluxes. An estimation of soil (plus root) $\mathrm{CO}_{2}$ flux is necessary for the computation of canopy photosynthesis. Soil (plus root) $\mathrm{CO}_{2}$ flux was not directly measured in this study. However, our nocturnal atmospheric $\mathrm{CO}_{2}$ flux data provided information on the respiratory release of $\mathrm{CO}_{2}$ from plant and soil (plus root). Plant respiration, estimated using eqn. (7), was subtracted from the nocturnal atmospheric $\mathrm{CO}_{2}$ flux to obtain the nocturnal soil $\mathrm{CO}_{2}$ flux. The values were then adjusted to the daytime soil temperature using a $Q_{10}$ factor of 2 (Kucera and Kirkham, 1971) to estimate the daytime soil $\mathrm{CO}_{2}$ flux. To minimize the effect of changing soil moisture and photosynthate on soil $\mathrm{CO}_{2}$ flux, the nocturnal $\mathrm{CO}_{2}$ flux data used here were limited to those from the nights preceeding or following the day under consideration. The magnitudes of computed daytime soil $\mathrm{CO}_{2}$ flux varied from 2 to $9 \mu \mathrm{mol}$ $\mathrm{m}^{-2} \mathrm{~s}^{-1}$ during the season, depending on soil temperature and leaf area index.

\section{RESULTS AND DISCUSSION}

Canopy photosynthesis, $\mathrm{A}_{c}$

Model results were compared against the micrometeorological measurements of fluxes on four selected days. These days were distributed through 
the growing season and were selected when the $\mathrm{CO}_{2}$ flux data were available during most of the day. The diurnal patterns of the modeled and measured $A_{\mathrm{c}}, \mathrm{PAR}, T, D, \Psi_{\mathrm{L}}$ and modeled $g_{\mathrm{s}}$ are presented in Figs. (1-4).

It was most clear on June 5 (Fig. 1). The prairie vegetation was in its early growth stage with the green $L \approx 1$.9. Atmospheric evaporative demand was moderate and the soil water was not limiting (extractable soil water, $\theta_{\mathrm{s}}$ for the $0-1.4 \mathrm{~m}$ depth was $78 \%$ ). The leaf water potential $\left(\Psi_{L}\right)$ of $A$. gerardii, which was the most dominant species, showed a diurnal variation typical for well-watered conditions and remained above $-1 \mathrm{MPa}$ throughout the day. The measured and modeled $A_{\mathrm{c}}$ followed the diurnal pattern of PAR and the magnitudes agreed within $4 \mu \mathrm{mol} \mathrm{m}^{-2} \mathrm{~s}^{-1}$. The diurnal pattern of $g_{\mathrm{s}}$ was similar to that of $A_{\mathrm{c}}$.

July 2 was partly cloudy in the morning and became clear in the afternoon (Fig. 2). The green $L$ reached its seasonal maximum of about 3.1 and the prairie vegetation was in the most vigorous stage of plant growth. On this day, the atmospheric evaporative demand was low to moderate and the soil water was not limiting $\left(\theta_{\mathrm{s}}=73 \%\right)$. The diurnal pattern of $\Psi_{\mathrm{L}}$ of $A$. gerardii was similar to that on June 5 and averaged $-1.1 \mathrm{MPa}$ during the midday. As would be expected for well-watered conditions, the diurnal patterns of measured and modeled $A_{\mathrm{c}}$ followed that of PAR quite closely. On average, the modeled values of $A_{\mathrm{c}}$ agreed with measured values of $A_{\mathrm{c}}$ within $7 \mu \mathrm{mol} \mathrm{m}^{-2} \mathrm{~s}^{-1}$. Again, the patterns of $A_{\mathrm{c}}$ and $g_{\mathrm{c}}$ were quite similar.

The sky was clear on July 30 (Fig. 3 ) and the moisture-stress conditions prevailed due to a low availability of soil water $\left(\theta_{s}=30 \%\right)$ and high atmospheric evaporative demand. On this day, $\Psi_{L}$ of $A$. gerardii decreased rapidly in the morning and stayed below $-2 \mathrm{MPa}$ for most of the day. The magnitudes of $A_{\mathrm{c}}$ were substantially lower than those observed on earlier days. The modeled values of $A_{\mathrm{c}}$ were consistently larger than those of measured $A_{\mathrm{c}}$, by about $5 \mu \mathrm{mol} \mathrm{m} \mathrm{m}^{-2} \mathrm{~s}^{-1}$. The overestimation of modeled $A_{\mathrm{c}}$ could partly be attributed to the errors involved in the measurements of green $L$ due to the partial rolling or folding of leaf blades of the dominant grass species under moisture stress conditions. The lack of validity of our assumption of constant $T, D$ and $\Psi_{L}$ within the canopy may have also contributed to this discrepancy. It is, however, worth noting that the diurnal patterns of measured and modeled $A_{\mathrm{c}}$ were quite similar on this day. The morning peak and the midday depression in modeled $A_{\mathrm{c}}$ were driven by a combination of substantially low values of $\Psi_{L}$ which caused $J_{\max }$ to decline, and to extremely high values of $D$ which led to a decrease in $g_{\mathrm{s}}$ and $C_{\mathrm{i}}$. The daily patterns in $g_{\mathrm{s}}$ were also characterized by a morning peak with a continuous decrease through most of the day.

Soil moisture conditions improved in mid-August with frequent and ample rainfall. The prairie vegetation began to senesce and the green $L$ decreased to about 2.3 on August 20. The soil water was not limiting $\left(\theta_{\mathrm{s}}=53 \%\right)$ on this 

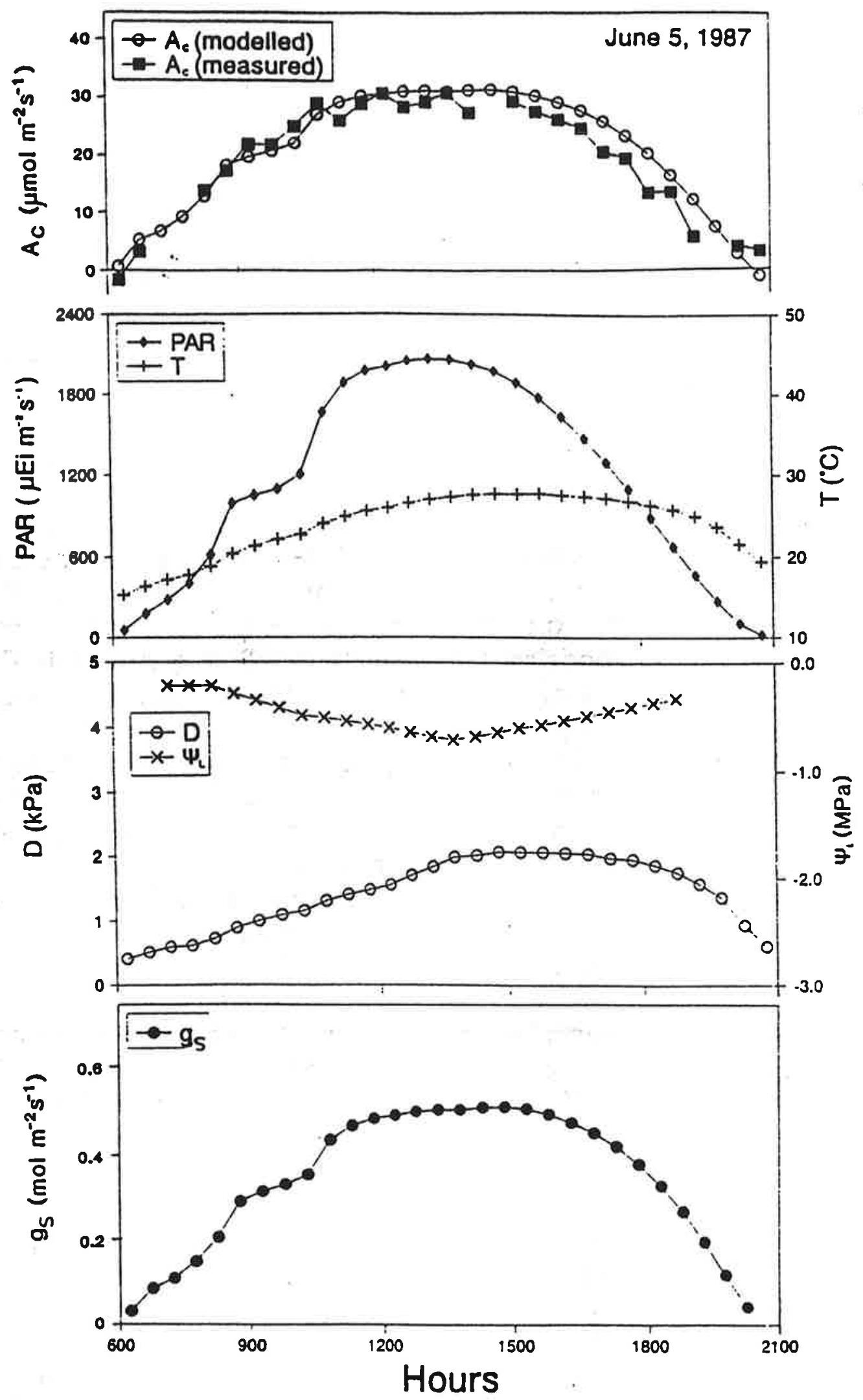

Fig. 1. Diumal responses of the modeled and measured canopy photosynthesis $\left(A_{c}\right)$ in a tallgrass prairie on 5 June 1987. Also shown are diurnal patterns of the photosynthetically active radiation (PAR) air temperature $(T)$, vapor pressure deficit $(D)$ and leaf water potential $\left(\Psi_{\mathrm{L}}\right)$ of .Andropogon gerardii, and modeled canopy stomatal conductance $\left(g_{s}\right)$. 

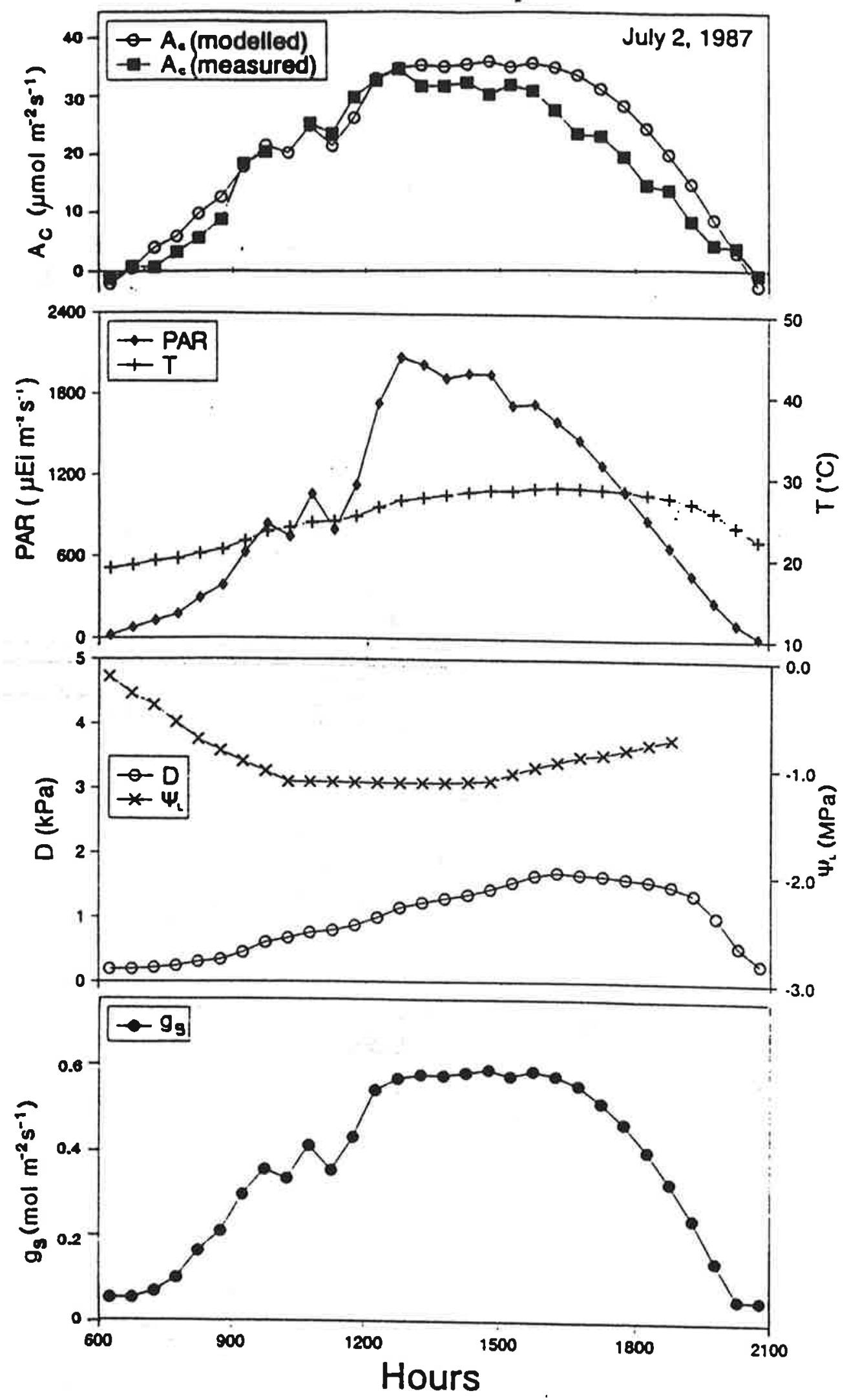

Fig. 2. Diumal responses of the modeled and measured canopy photosynthesis $\left(A_{c}\right)$ in a tallgrass prairie on 2 July 1987 . Also shown are diumal patterns of the photosynthetically active radiation (PAR), air temperature $(T)$, vapor pressure deficit $(D)$, and leaf water potential $\left(\Psi_{L}\right)$ of Andropogon gerardii. and modeled canopy stomatal conductance $\left(g_{s}\right)$. 

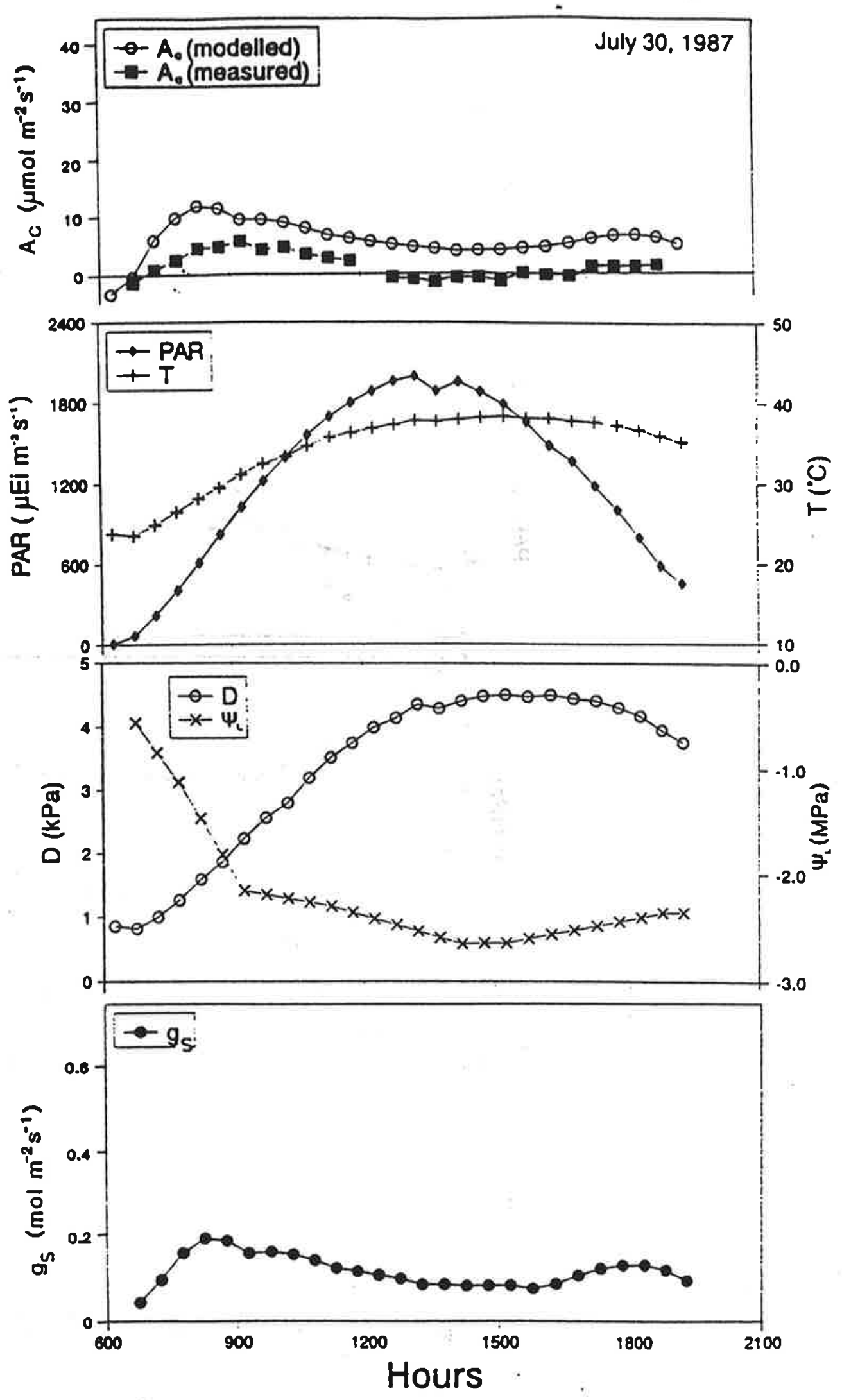

Fig. 3. Diurnal responses of the modeled and measured canopy photosynthesis $\left(. t_{c}\right)$ in a tallgrass prairie on 30 July 1987 . Also shown are diurnal patterns of the photosynthetically active radiation (P.AR), air temperature $(T)$, vapor pressure deficit $(D)$ and leat water potential $\left(\Psi_{L}\right)$ of . Indropogon gerardii, and modeled canopy stomatal conductance $\left(g_{\mathrm{s}}\right)$. 


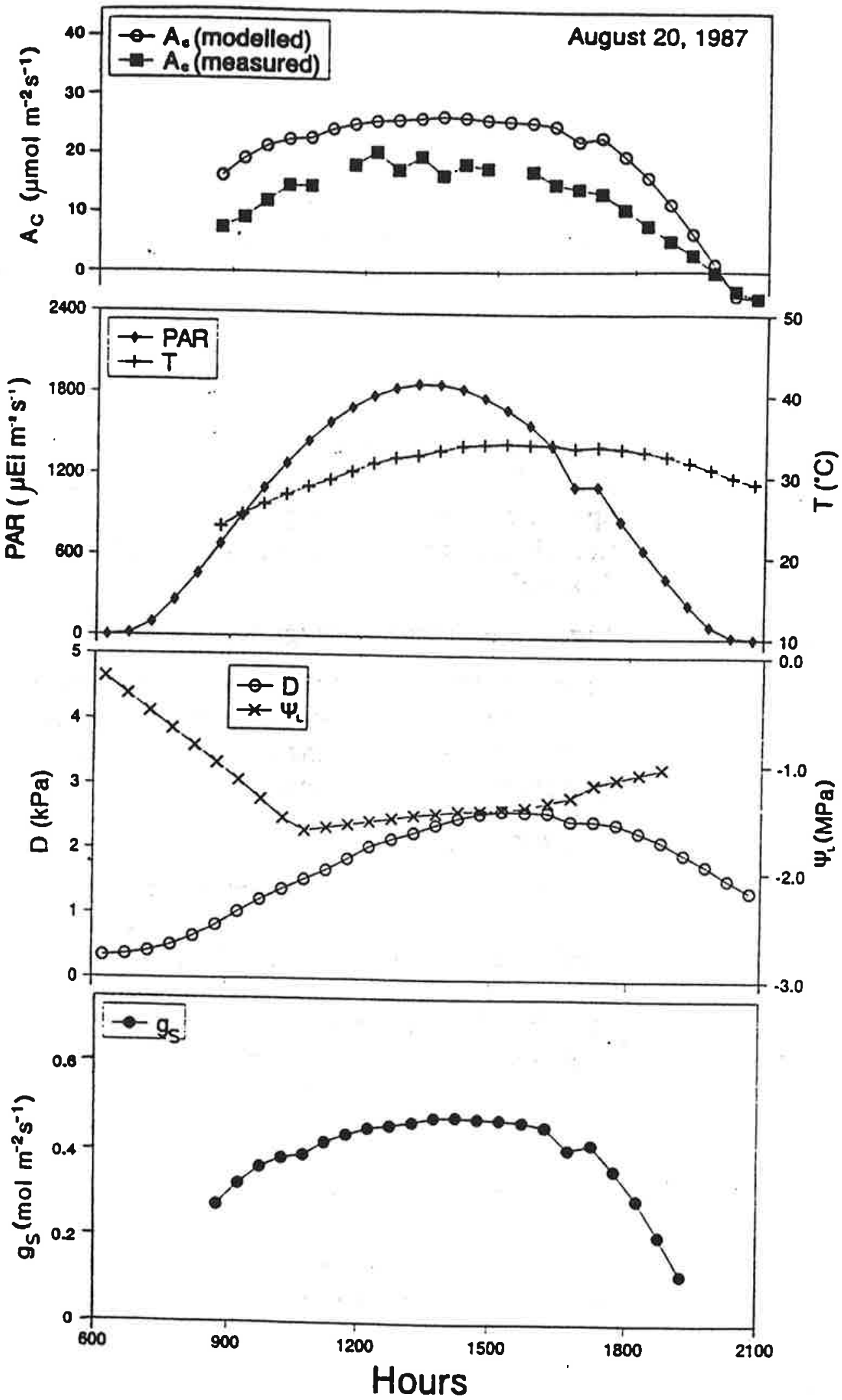

Fig. 4. Diurnal responses of the modeled and measured canopy photosynthesis $\left(A_{c}\right)$ in a tallgrass prairie on 20 August 1987. Also shown are diumal patterns of the photosynthetically active radiation (PAR), air temperature $(T)$, vapor pressure deficit $(D)$ and leaf water potential $\left(\Psi_{L}\right)$ of Andropogon gerardii, and modeled canopy stomatal conductance $\left(g_{3}\right)$. 
day and the atmospheric evaporative demand was moderate. The $\Psi_{\mathrm{L}}$ of $A$. gerardii stayed above $-1.5 \mathrm{MPa}$ for most of the day. The diurnal patterns of the measured and modeled $A_{\mathrm{c}}$ were similar, but the modeled $A_{\mathrm{c}}$ exceeded the measured values by about $7 \mu \mathrm{mol} \mathrm{m}^{-2} \mathrm{~s}^{-1}$ (Fig. 4). This difference might have been partly due to a reduced availability of nutrients, leaf aging and other developmental effects induced by the occurrence of the severe water stress during the dry period, factors not considered in the present model.

\section{Canopy stomatal conductance, $\mathbf{g}_{s}$}

The canopy stomatal conductance $\left(g_{s}\right)$, discussed above, is the serial, areaweighted sum of the values of leaf stomatal conductance $\left(g_{\mathrm{s}}\right)$, obtained from eqn. (10) in conjunction with the leaf photosynthesis model. In Fig. 5(A) and 5 (B), the diurnal variations in modeled $g_{\mathrm{s}}$ are compared against the canopy surface conductance, $\boldsymbol{g}_{\mathrm{S}(\mathrm{PM})}$. By rearranging the Penman-Monteith equation (Monteith, 1965) $\boldsymbol{g}_{\mathrm{S}(\mathrm{PM})}$ was determined from the measured latent heat flux $(\lambda E)$

$$
1 / g_{\mathrm{S}(\mathrm{PM})}=[(s / \gamma) \beta-1] / \boldsymbol{g}_{\mathrm{a}}+\rho c_{\mathrm{p}} D /(\gamma \lambda E)
$$

where $s$ is the slope of the saturated vapor pressure-temperature curve, $\gamma$ is the psychrometric constant, $\beta$ is the Bowen ratio, $\rho$ is the density of air, $c_{\mathrm{p}}$ is the specific heat of air and $D$ is vapor pressure deficit. The aerodynamic conductance, $\boldsymbol{g}_{\mathrm{a}}$, was computed as

$$
1 / g_{\mathrm{a}}=r_{\mathrm{am}}+r_{\mathrm{b}}
$$

where $r_{\mathrm{am}}\left(=\bar{\mu} / u_{*}^{2}\right)$ is the aerodynamic resistance for momentum transfer and $r_{\mathrm{b}}\left[\approx\left(2 / k u_{*}\right)\left(\kappa / D_{\mathrm{v}}\right)^{2 / 3}\right]$ is the excess resistance term (see e.g. Thom (1972) and Wesley and Hicks (1977) for further details). Here, $k$ is von Karman's constant, $\kappa$ is the thermal diffusivity and $D_{\mathrm{v}}$ is the molecular diffusivity of water vapor.

Figure 5 includes data from June 5, a day when soil moisture was not limiting (Fig. 5(A)) and from July 30, a day with moisture stress (Fig. 5(B)). The diurnal patterns of $\boldsymbol{g}_{\mathrm{s}}$ from the model were in reasonable agreement with those of $g_{\mathrm{S}(\mathrm{PM})}$ under well-watered conditions (June 5 ). The model underestimated $g_{\mathrm{S}(\mathrm{PM})}$, on average, by $0.2 \mathrm{~mol} \mathrm{~m}^{-2} \mathrm{~s}^{-1}$. This may be partly because $g_{\mathrm{S}(\mathrm{PM})}$ includes the contribution from the soil evaporation, especially when $L$ is small and the soil water was not limiting. On July 30, the model yielded excellent simulation of the magnitude and the diurnal pattern of $g_{S(P M)}$. The differences between the values from the modeled $g_{\mathrm{s}}$ and $g_{\mathrm{S}(\mathrm{PM})}$ were less than $0.05 \mathrm{~mol} \mathrm{~m}^{-2} \mathrm{~s}^{-1}$. On this day, the contribution from the soil evaporation was small because of low availability of soil water and fuller vegetative cover.

These modeled and measured canopy conductance comparisons are encouraging in terms of estimating $\lambda E$. The computation of $\lambda E$ is more sensitive 

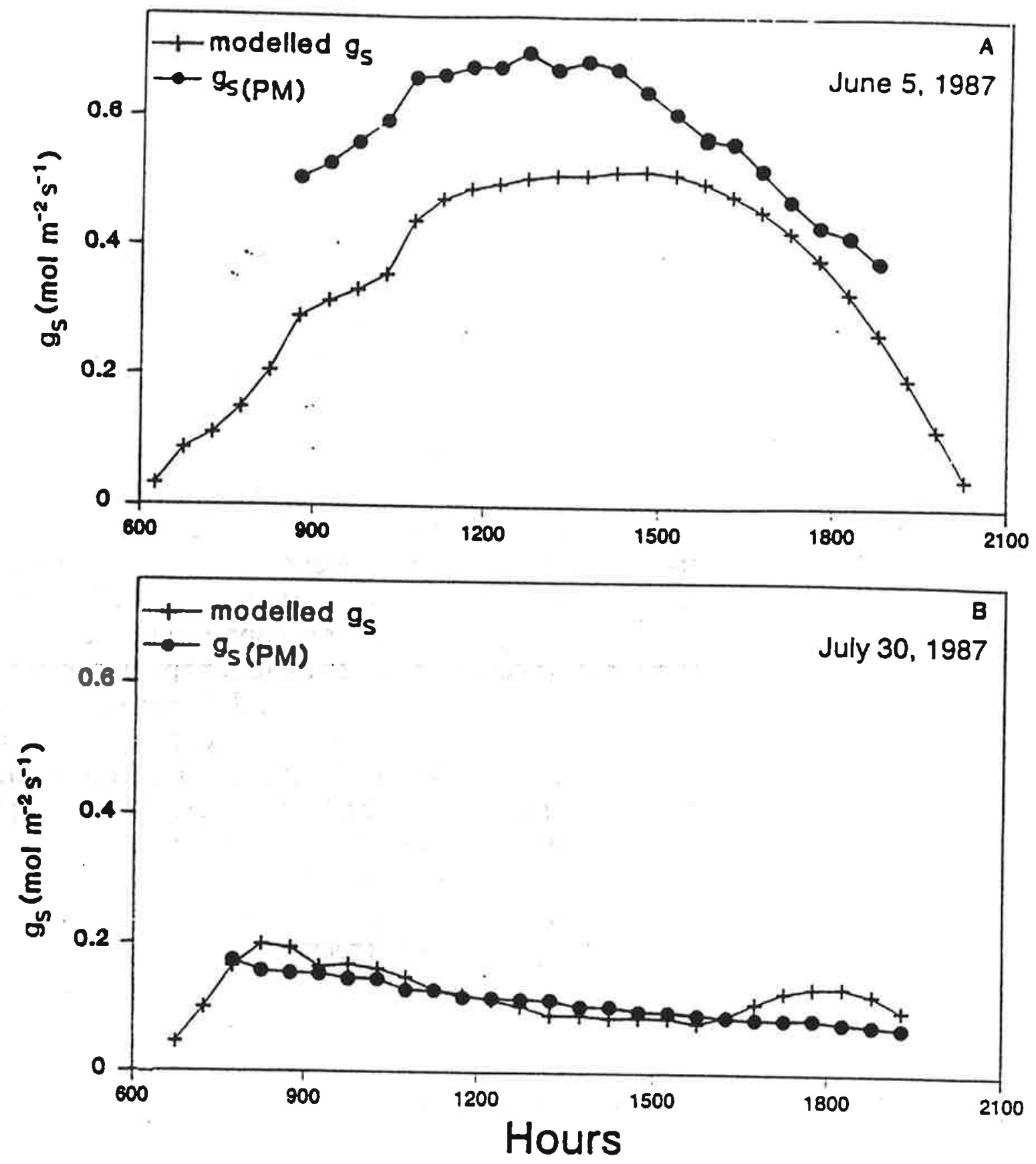

Fig. 5. Comparison of the modeled canopy conductances $\left(g_{s}\right)$ with the measured canopy surface conductance ( $g_{S(P M)}$ ) on (A) 5 June 1987, a day when soil water was not limiting and (B) 30 July 1987 , a day with moisture stress.

to errors in $g_{s}$ under moisture stress conditions (see e.g. Kim and Verma, 1991 ). For example, $30 \%$ error in $g_{s}$ would result in $<10 \%$ error in $\lambda E$ under well-watered conditions and $25 \%$ error in $\lambda E$ under moisture stress conditions. As indicated in Fig. 5(A) and $5(\mathrm{~B})$ the agreement between the modeled $g_{s}$ and the measured $g_{S(P M)}$ was, on the average, within $30 \%$ under wellwatered conditions and within 10\% under moisture stress conditions. The 
corresponding errors in $\lambda E$ estimation would be $<10 \%$ under both wellwatered and moisture stress conditions.

\section{CONCLUDING REMARKS}

We have employed a physiologically and biochemically based model of leaf photosynthesis in a temperate grassland ecosystem. The model takes into account the known responses of leaf photosynthesis to absorbed PAR, temperature, intercellular $\mathrm{CO}_{2}$ concentration, leaf water potential, vapor pressure deficit and stomatal conductance. The modeled canopy photosynthesis was tested against fluxes measured in the field. The results indicate that the model can be used to provide reasonable estimates of canopy photosynthesis under well-watered conditions. The model tended to overestimate under moisture stress conditions; however, it predicted the diurnal variation (morning peak and midday depression ) adequately. Also, the prediction of canopy stomatal conductance was reasonable under both well-watered and moisture stress conditions, suggesting that this approach may be used, in conjunction with a combination equation, to estimate canopy transpiration.

The $\mathrm{C}_{4}$ leaf photosynthesis model described here is empirical. Future studies in the modeling of $\mathrm{C}_{4}$ photosynthesis would require, among other things, the elucidation of the mechanism and kinetics of enzymes unique to the $C_{4}$ cycle, and the confirmation of the values for kinetic properties. Further studies on the effect of water stress on RuBP carboxylation and regeneration capacities are also needed in relation to the roles of soil and plant water status (e.g. Turner et al., 1985; Gollan et al., 1985; Kramer, 1988). Inclusion of more detailed canopy microclimate models (e.g. higher-order closure models, Lagrangian-frame models) may improve our ability to deal with the reality in nature.

\section{ACKNOWLEDGEMENTS}

This study was supported by the National Aeronautics and Space Administration under Grant \#NAG5-890 and by the National Science Foundation under Grant ATM-8519026. We are grateful to Drs. J.M. Norman, H.W. Polley and T.J. Arkebauer for their valuable suggestions during this study, and for their comments on the manuscript. We thank H.D. Earl, S.D. Sharp and J.R. Hines for technical assistance in instrument maintenance and data processing, and Dr. J. Stubbendieck for his help in estimating species composition. Special thanks are due to R.J. Clement for his valuable help in data collection and processing. 


\section{REFERENCES}

Anderson, J.M. and Osmond. C.B., 1987. Shaded-sun responses: compromises between acclimation and photoinhibition. In: D.J. Kyle, C.B. Osmond, C.J. Amtzen (Editors). Topics in Photosynthesis: Photoinhibition. Vol. 9. Elsevier, Amsterdam, pp. 1-38.

Badger. M.R. and Collatz, G.J., 1977. Studies on the kinetic mechanism of ribulose-1,5-biphosphate carboxylase and oxygenase reactions, with particular reference to the effect of temperature on kinetic parameters. Carnegie Inst. Washington. Yearbook, 76: 355-361.

Baldocchi, D.D., Hicks B.B. and Meyers. T.P., 1988. Measuring biosphere-atmosphere exchanges of biologically related gases with micrometeorological methods. Ecology, 69: 1331-
1340 .

Ball, J.T., 1987. Calculations related to gas exchange. In: E. Zeiger, G. Farquhar and I. Cowan (Editors). Stomatal Functions. Stanford University Press, CA, pp. 445-476.

Ball, J.T. Woodrow, I.E. and Berry, J.A.. 1987. A model predicting stomatal conductance and its contribution to the control of photosynthesis under different environmental conditions. In: J. Biggins (Editor), Progress in Photosynthesis Research, Vol. IV. Martinus-Nijhoff,
Dordrecht, pp. 221-224.

Box, E.O., 1988. Estimating the seasonal carbon source-sink geography of a natural, steadystate terrestrial biosphere. J. Appl. Meteorol., 27: 1109-1124.

Brooks, A. and Farquhar, G.D., 1985. Effect of temperature on the $\mathrm{CO}_{2} \mathrm{O}_{2}$ specificity of ribulose-1,5-bisphosphate carboxylase/oxygenase and the rate of respiration in the light. Planta,
165: 397-406.

Campbell, G.S., 1977. An Introduction to Environmental Biophysics. Springer-Verlag, New York.
159 pp.

Farquhar, G.D., von Caemmerer, S. and Berry, J.A., 1980. A biochemical model of photosynthetic $\mathrm{CO}_{2}$ assimilation in leaves of $\mathrm{C}_{3}$ species. Planta, 149: 78-90.

Farquhar, G.D. and von Caemmerer, S., 1982. Modelling of photosynthetic response to environmental conditions. In: O.L. Lange, P.S. Nobel, C.B. Osmond and H. Ziegler (Editors), Encyclopedia of Plant Physiology, New Series 12B. Springer-Verlag, Berlin, pp. 549-587. Farquhar, G.D. and Sharkey, T.D., 1982. Stomatal conductance and photosynthesis. Annu. Rev.
Plant Physiol., 33: 317-345.

Fung, I., Prentice, K., Matthews, E.. Lerner, J. and Russell, G., 1983. Three-dimensional tracer model study of atmospheric $\mathrm{CO}_{2}$ : response to seasonal exchanges with the terrestrial biosphere. J. Geophys. Res., 88: 1281-1294.

Gifford. R.M., 1989. Interactions with vegetation. In: G.I. Pearman (Editor), Greenhouse: Planning for Climate Change. CSIRO. Australia. pp. 83-89.

Gollan. T., Turner. N.C. and Schulze, E.-D., 1985. The responses of stomata and leaf gas exchange to vapor pressure deficits and soil water content. III. In the sclerophyllous woody species Nerium oleander. Oecologia, 65: 356-362.

Grant. R.F., 1989. Test of a simple biochemical model for photosynthesis of maize and soybean leaves. Agric. For. Meteorol., 48: 59-74.

Grant, R.F.. Peters, D. B.. Larson, E.M. and Huck, M.G.. 1989. Simulation of canopy photosynthesis in maize and soybean. Agric. For. Meteorol., 48: 75-92.

Harley, P.C.. Weber, J..t. and Gates, D.M., 1985. Interactive effects of light, leaf temperature. carbon dioxide and oxygen on photosynthesis in soybean. Planta. 165: 249-263.

Hesketh, J.D., 1980. Predicting canopy photosynthesis from gas exchange studies in controlled environments. In: J.D. Hesketh and J.W. Jones (Editors), Predicting Photosynthesis for Ecosystem Model. Vol. I. CRC Press, Boca Raton, FL, pp: 37-50.

Jarvis. P.G. and Morison. J.I.L.. 1981. The control of transpiration and photosynthesis by stomata. In: P.G. Jarvis and T.A. Mansfield (Editors), Stomatal Physiology. Cambridge University Press. Cambridge. pp. 248-279. 
Kaimal. J.C., 1975. Sensors and techniques for direct measurement of turbulent fluxes and profiles in the atmospheric surface layer. Atmos. Technol., 7:7-14.

Kanemasu, E.T., Wesely, M.L., Hicks, B.B. and Heilman, J.L., 1979. Techniques for calculating energy and mass fluxes. In: B.L. Barfield and J.F. Gerber (Editors), Modification of the Aerial Environment of Crops. Am. Soc. Agric. Eng., St. Joseph, MI, pp. 156-182.

Kim. J. and Verma, S.B., 1990a. Components of surface energy balance in a temperate grassland ecosystem. Boundary-Layer Meteorol., 51: 401-417.

$\mathrm{Kim}, \mathrm{J}$. and Verma, S.B., 1990b. Carbon dioxide exchanges in a temperate grasstand ecosystem. Boundary-Layer Meteorol., 52: 135-149.

Kim. J. and Verma, S.B., 1991. Modeling canopy stomatal conductance in a temperate grassland ecosystem. Agric. For. Meteorol., 55: 149-166.

Kramer, P.J., 1988. Changing concepts regarding plant water relations. Plant Cell Environ., 11: 565-568.

Kucera. C.L. and Kirkham, D.R., 1971. Soil respiration studies in tallgrass prairie in Missouri. Ecology, 52: 912-915.

Monteith, J.L., 1965. Evaporation and environment. In: G.E. Fogg (Editor), The State and Movement of Water in Living Organisms. Academic Press, New York, pp. 205-234.

Norman, J.M., 1982. Simulation of microclimates. In: J.L. Hatfield and I.J. Thompson (Editors), Biometeorology in Integrated Pest Management. Academic Press, New York, pp. 6599.

Norman, J.M., 1986. Instrumentation use in a comprehensive description of plant-environment interactions. In: W. Gensler (Editor), Advanced Agricultural Instrumentation. Martinus Nijhof, pp. 149-307.

Norman, J.M. and Arkebauer, T.J., 1991. Predicting canopy light-use efficiency from leaf characteristics. In: J.T. Ritchie and R.J. Hanks (Editors), ASA Monograph Modeling Plant and Soil Systems (in press).

Norman, J.M. and Polley, H.W., 1989. Canopy photosynthesis. In: W.R. Briggs (Editor), Photosynthesis. Allan R. Liss, New York, pp. 227-241.

Polley, H.W., Norman, J.M., Arkebauer, T.J., Walter-Shea, E.A., Greegor, D.H.. Jr. and Bramer, B., 1991. Gas exchange of Andropogon gerardii Vitman, Panicum virgatum L., and Sorghastrum nutans (L.) Nash in a tallgrass prairie. J. Geophys. Res., submitted.

Price. D.T. and Black, T.A., 1989. Estimation of forest transpiration and $\mathrm{CO}_{2}$ uptake using the Penman-Monteith equation and a physiological photosynthesis model. In: T..t. Black. D.L. Spittlehouse, N.D. Dovak, N.D. and D.T. Price (Editors), Estimation of Areal Evapotranspiration. IAHS Publication No. 177, IAHS Press. Institute of Hydrology, Wallingford. pp. 213-227.

Richards. F.J., 1969. The quantitative analysis of growth. In: F.C. Stewart (Editor). Plant Physiology. Vol. 5A. Academic Press, New York. pp. 3-76.

Schoolfield. R.M., Sharp, P.J.H. and Magnuson. C.E., 1981. Non-linear regression of biological temperature-dependent rate models based on absolute reaction-rate theory. J. Theor. Biol. 88: 719-731.

Sellers, P.J.. Mintz. Y., Sud, Y.C. and Dalcher. A.. 1986. A simple biosphere model (SiB) for use within general circulation models. J. Atmos. Sci., 43: 505-531.

Sellers. P.J.. Hall, F.G., Asrar. G., Strebel, D.E. and Murphy, R.E., 1988. The First ISLSCP Field Experiment (FIFE). Bull. Am. Meteorol. Soc.; 69: 22-27.

Sharkey, T.D. and Badger, M.R., 1982. Effects of water stress on photosynthetic electron transport, photophosphorylation. and metabolite levels of Yanthium strumarium mesophyll cells. Planta. 156: 199-206.

Sharkey, T.D. and Seemann, J.R., 1989. Mild water stress effects on carbon-reduction-cycle intermediates. ribulose biphosphate carboxylase activity, and spatial homogeneity of photosynthesis in intact leaves. Plant Physiol., 89: 1060-1065. 
Sharp, R.E., Matthews, M.A. and Boyer, J.S., 1984. Kok effect and the quantum yield of photosynthesis. Light partially inhibits dark respiration. Plant Physiol., 75: 95-101.

Tenhunen, J.D. and Harley, P.C., 1988. Modeling the photosynthetic response to environmental factors. Agron. Abstr., 80: 119.

Thom, A.S., 1972. Momentum, mass and heat exchange of vegetation. Q. J. R. Meteorol. Soc., 98: 124-134.

Turner, N.C., Schulze, E.-D. and Gollan, T., 1985. The responses of stomata and leaf gas exchange to vapor pressure deficits and soil water content. II. In the mesophytic herbaceous species Helianthus annuus. Oecologia (Berlin), 65: 348-355.

Verma, S.B., 1990. Micrometeorological methods for measuring surface fluxes of mass and energy. Remote Sensing Rev., 5: 99-115.

Von Caemmerer, S. and Farquhar, G.D., 1984. Effects of partial defoliation, changes of irradiance during growth, short-term water stress and growth at enhanced $\mathrm{p}\left(\mathrm{CO}_{2}\right)$ on the photosynthetic capacity of leaves of Phaseolus vulgaris L. Planta, 160: 320-329.

Walter-Shea, E.A., Blad, B.L., Starks, P.J., Hays, C.J., Mesarch, M.A. and Middleton, E.M., 1990. Bidirectional reflectance, leaf optical and physiological properties of prairie vegetation. Symposium on FIFE, 7-9 February, American Meteorological Society, Anaheim, CA, 70 pp.

Weiss, A. and Norman, J.M., 1985. Partitioning solar radiation into direct and diffuse, visible and near-infrared components. Agric. For. Meteorol., 34: 205-213.

Wesely, M.L. and Hicks, B.B., 1977. Some factors that affect the deposition rates of sulfur dioxide and similar gases on vegetation. J. Air. Pollut. Control Assoc., 27: 1110-1115.

Wong, S.C., Cowan, I.R. and Farquhar, G.D., 1979. Stomatal conductance correlates with photosynthetic capacity. Nature, 282: 424-426.

\section{APPENDIX: SYMBOLS AND VALUES USED}

\begin{tabular}{|c|c|c|c|}
\hline$a_{1}$ & $\begin{array}{l}\text { Constant in eqn. } \\
(6)\end{array}$ & $\begin{array}{l}290 \text { (A. gerardii }) \\
360(\text { S. nutans }) \\
320(P . \text { virgatum })\end{array}$ & $\begin{array}{l}\text { Estimated from the } \\
\text { data of Polley } \\
\text { et al. (1991) }\end{array}$ \\
\hline$a_{2}-a_{6}$ & $\begin{array}{l}\text { Constants in eqn. } \\
(6)\end{array}$ & $\begin{array}{l}a_{2}(-8000) \\
a_{3}(-147200) \\
a_{4}(297.0) \\
a_{5}(436000) \\
a_{6}(323.5) \\
\text { (same for all } \\
\text { species) }\end{array}$ & $\begin{array}{l}\text { H.W. Polley, } \\
\text { personal } \\
\text { communication, } \\
1990\end{array}$ \\
\hline $\begin{array}{l}A \\
\left(\mu \mathrm{mol} \mathrm{m}^{-2}\right. \\
\left.\mathrm{s}^{-1}\right) \\
A_{\mathrm{c}} \\
\left(\mu \mathrm{mol} \mathrm{m} \mathrm{m}^{-2}\right. \\
\left.\mathrm{s}^{-1}\right) \\
\mathrm{AG}\end{array}$ & $\begin{array}{l}\text { Rate of } \mathrm{CO}_{2} \\
\text { assimilation of } \\
\text { a leaf } \\
\text { Canopy } \\
\text { photosynthesis }\end{array}$ & 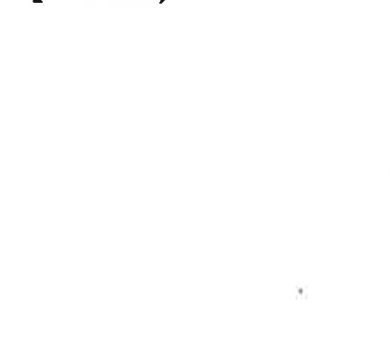 & \\
\hline $\mathrm{AG}$ & $\begin{array}{l}\text { Andropogon } \\
\text { gerardii }\end{array}$ & & \\
\hline
\end{tabular}




\begin{tabular}{|c|c|c|c|}
\hline$b_{\mathrm{D}}$ & $\begin{array}{l}\text { Constant in eqn. } \\
\text { (12) }\end{array}$ & $\begin{array}{l}0.18 \text { (A. gerardii }) \\
0.06(S . \text { nutans }) \\
0.09(P . \text { virgatum })\end{array}$ & $\begin{array}{l}\text { Kim and Verma } \\
\text { (1991) }\end{array}$ \\
\hline $\begin{array}{l}C_{\mathrm{a}} \\
(\mu \mathrm{bar})\end{array}$ & $\begin{array}{l}\text { Partial pressure } \\
\text { of } \\
\text { ambient } \mathrm{CO}_{2}\end{array}$ & 330 & $\begin{array}{l}\text { J.M. Norman, } \\
\text { personal } \\
\text { communnication, } \\
1990\end{array}$ \\
\hline $\begin{array}{l}C_{\mathrm{i}} \\
(\mu \mathrm{bar}) \\
D \\
(\mathrm{kPa})\end{array}$ & $\begin{array}{l}\text { Intercellular } \\
\text { partial } \\
\text { pressure of } \mathrm{CO}_{2} \\
\text { Vapor pressure } \\
\text { deficit }\end{array}$ & & \\
\hline $\begin{array}{l}E \\
\left(\mathrm{~J} \mathrm{~mol} \mathrm{~m}^{-1}\right)\end{array}$ & Activation energy & $\begin{array}{l}59356\left(K_{\mathrm{c}}\right), \\
35948\left(K_{\mathrm{o}}\right) \\
58520\left(V_{\mathrm{c}(\max )}\right),\end{array}$ & $\begin{array}{l}\text { Farquhar et al. } \\
\text { (1980) }\end{array}$ \\
\hline $\begin{array}{l}g_{\mathrm{s}} \\
\left(\mathrm{mol} \mathrm{m} \mathrm{m}^{-2} \mathrm{~s}^{-1}\right)\end{array}$ & $\begin{array}{l}\text { Leaf stomatal } \\
\text { conductance } \\
\text { to water vapor }\end{array}$ & 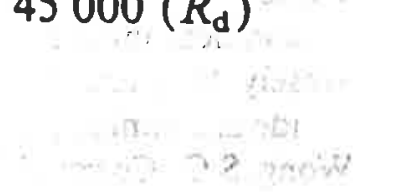 & Polley et al. (1991) \\
\hline$\Theta$ & $\begin{array}{l}\text { Convexity of the } \\
\text { light response } \\
\text { curve of } J\end{array}$ & $\begin{array}{l}0.1 \text { (A. gerardii) } \\
0.2 \text { (S. nutans) } \\
0.2 \text { (P. virgatum) }\end{array}$ & Polley et al. (1991) \\
\hline $\begin{array}{l}g_{\mathrm{s}} \\
\left(\mathrm{mol} \mathrm{m}^{-2} \mathrm{~s}^{-1}\right)\end{array}$ & $\begin{array}{l}\text { Canopy stomatal } \\
\text { conductance } \\
\text { to water vapor }\end{array}$ & & \\
\hline $\begin{array}{l}I \\
\left(\mu \mathrm{mol} \mathrm{m} \mathrm{m}^{-2}\right. \\
\left.\mathrm{s}^{-1}\right)\end{array}$ & $\begin{array}{l}\text { Absorbed } \\
\text { photosynthetically } \\
\text { active radiation } \\
\text { by a leaf }\end{array}$ & & - \\
\hline $\begin{array}{l}J \\
\left(\mu \mathrm{Eq} \mathrm{m}^{-2}\right. \\
\left.\mathrm{s}^{-1}\right)\end{array}$ & $\begin{array}{l}\text { Potential rate of } \\
\text { electron } \\
\text { transport }\end{array}$ & & \\
\hline $\begin{array}{l}J^{\prime} \\
\left(\mu \mathrm{Eq} \mathrm{m}^{-2}\right. \\
\left.\mathrm{s}^{-1}\right)\end{array}$ & $\begin{array}{l}\text { Electron } \\
\text { transport limit } \\
\text { on rate of } \\
\text { carboxylation }\end{array}$ & & \\
\hline $\begin{array}{l}J_{\max } \\
\left(\mu \mathrm{Eq} \mathrm{m} \mathrm{m}^{-2}\right. \\
\left.\mathrm{s}^{-1}\right)\end{array}$ & $\begin{array}{l}\text { Light-saturated } \\
\text { potential rate of } \\
\text { electron } \\
\text { transport }\end{array}$ & $\begin{array}{ll}160^{\prime} & (\text { A. gerardii }) \\
200^{\prime} & (\text { S. nutans }) \\
175^{\prime} & (\text { P. virgatum })\end{array}$ & $\begin{array}{l}\text { Estimated from the } \\
\text { data of Polley } \\
\text { et al. (1991) }\end{array}$ \\
\hline
\end{tabular}




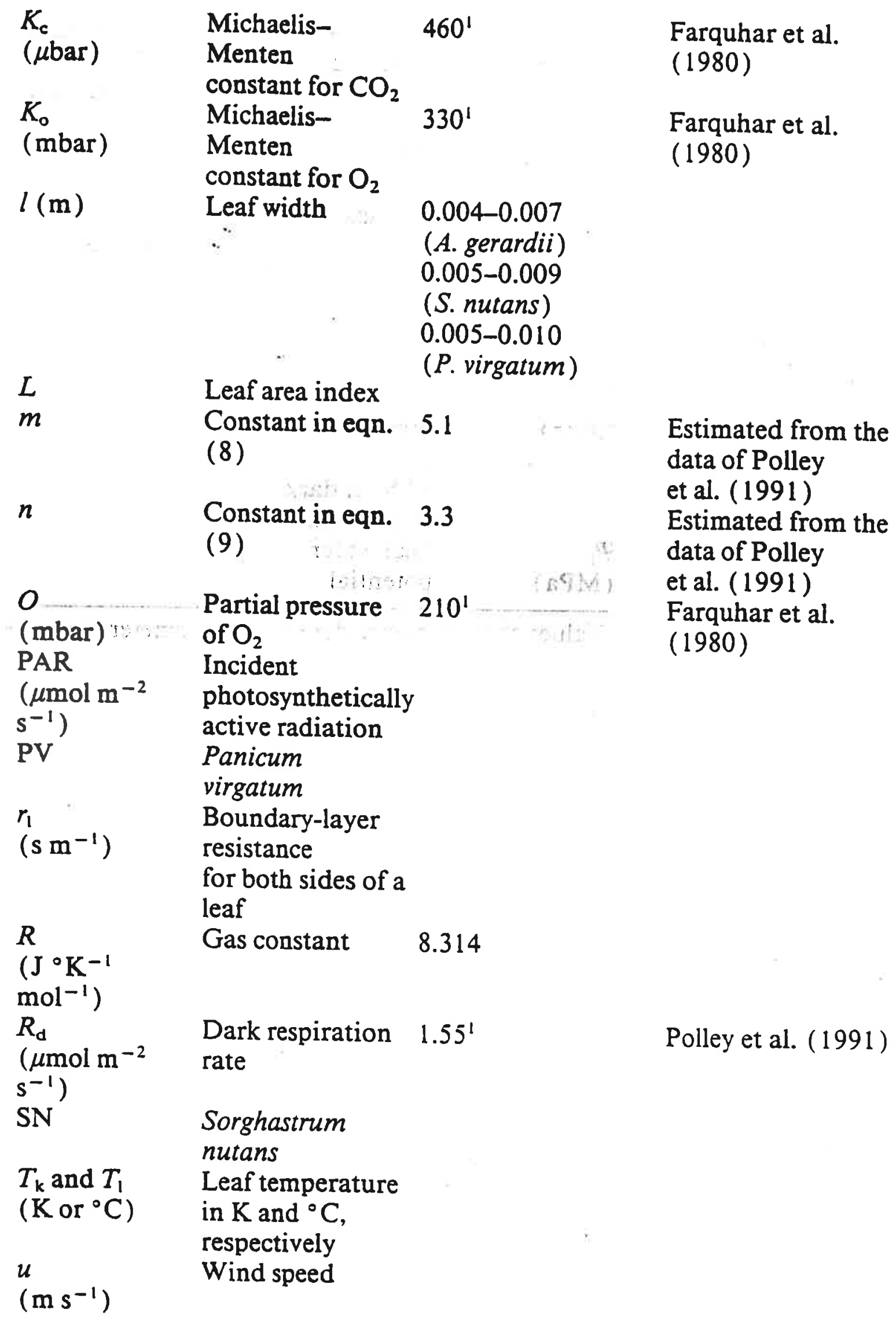




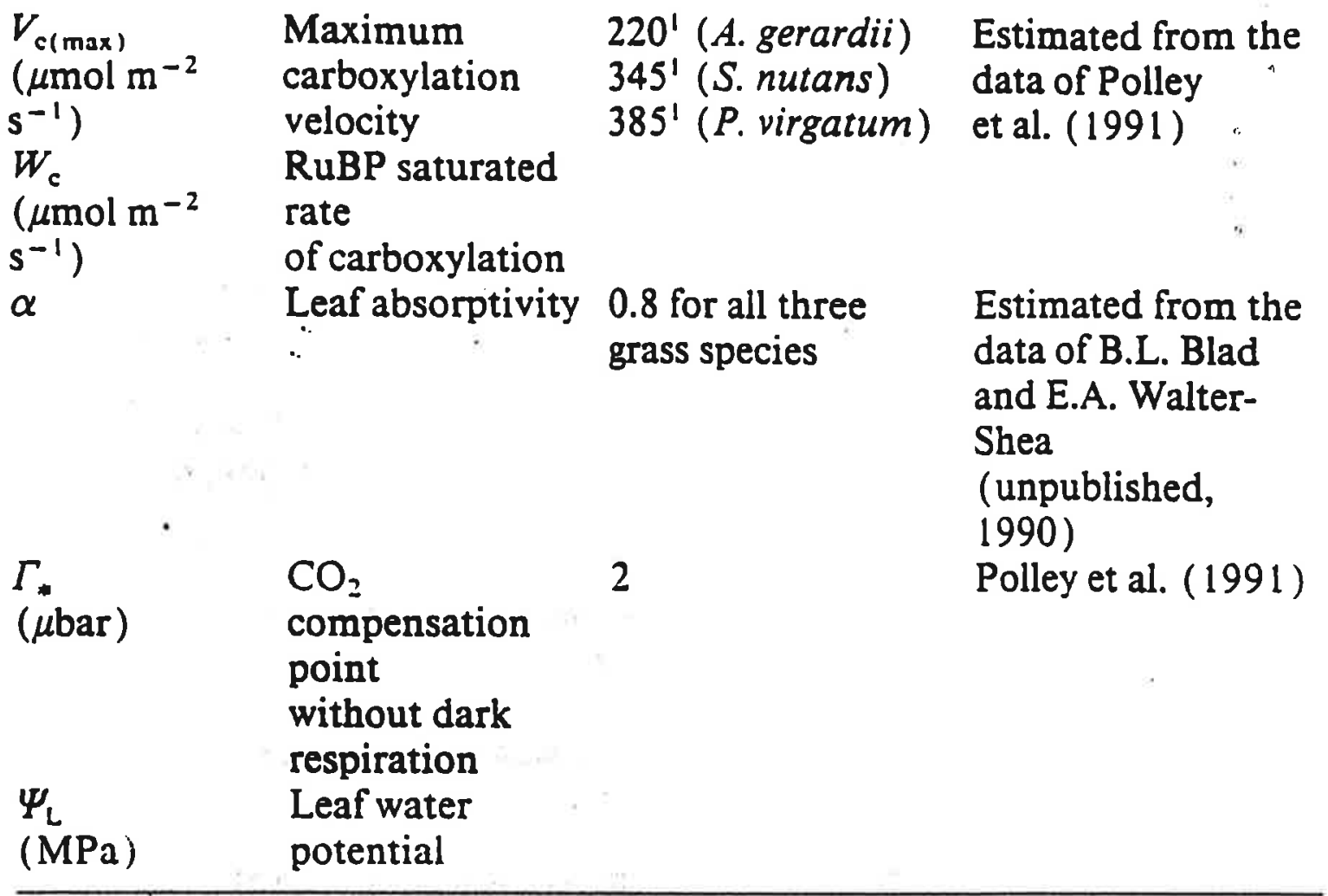

'Values of terriperature dependent parameters are given at $25^{\circ} \mathrm{C}$. 
